\title{
First record of the alien pest Rhaponticum repens (Compositae) in the Iberian Peninsula
}

\author{
J. LÓPEZ-ALVARADO ${ }^{1,2}$, M. B. CRESPO ${ }^{3}$, N. GARCIA-JACAS ${ }^{1}$, M. A. ALONSO ${ }^{3}$, \\ L. VILAR ${ }^{4}$, J. C. CRISTÓBAL ${ }^{3}$, A. SUSANNA ${ }^{1}$, F. MARTÍNEZ-FLORES ${ }^{3}$, \\ A. JUAN ${ }^{3} \&$ L. SÁEZ \\ ${ }^{1}$ Institut Botànic de Barcelona (IBB-CSIC-ICUB), Psg. del Migdia s/n., E-08038 Barcelona, Spain \\ ${ }^{2}$ Dipartimento di Botanica ed Ecologia Vegetale, Facoltà di Scienze Matematiche, Fisiche e Naturali, \\ Università degli Studi di Sassari, Via Piandanna 4, I-07100 Sassari, Italy \\ ${ }^{3}$ CIBIO (Instituto de la Biodiversidad), Universidad de Alicante, P. O. Box 99, E-03080 Alicante, Spain \\ ${ }^{4}$ Facultat de Ciències, Campus de Montilivi, Universitat de Girona, E-17071 Girona, Spain \\ ${ }^{5}$ Unitat de Botànica, Universitat Autònoma de Barcelona, E-08193 Bellaterra, Spain
}

Author for correspondence: L. Sáez (gymnesicum@yahoo.es)

Editor: R. Vilatersana

Received 28 July 2011; Accepted 5 October 2011

\begin{abstract}
First record of the alien pest Rhaponticum repens (Compositae) in the Iberian Peninsula.- Rhaponticum repens is reported for the first time for the flora of the Iberian Peninsula. The species is native from Central Asia and has become invasive in Argentina, Canada, Europe and the USA. It was detected for the first time in abandoned fields from Vilablareix, near the city of Girona (Catalonia, Spain) and in the valley of the Vinalopó in Alicante (Valencia, Spain), where it was collected as early as in 1959 but misdentified. Molecular data, based on nrDNA region ITS, suggest that the reported populations may be closely related to plants from the United States. Due to the extremely noxious character of the species and the possible relationship of Spanish plants with the invasive American populations, some kind of monitoring is recommended.
\end{abstract}

Key words: Alien species; Compositae; Iberian Peninsula.

\section{Resumen}

Rhaponticum repens (Compositae), una nueva planta alóctona para la Península Ibérica.- Se cita por primera vez la especie Rhaponticum repens para la flora de la Península Ibérica. Rhaponticum repens es una especie nativa de Asia central que actúa como invasora en diversos países como Argentina, Canadá o los Estados Unidos. Se ha encontrado por primera vez en campos de cultivo abandonados en el pueblo de Vilablareix, cerca de la ciudad de Girona (Cataluña, España) y en el valle del Vinalopó (Valencia, España), donde fue recolectada y mal identificada en 1959. Los datos moleculares, obtenidos a partir de la región ITS del nrDNA, sugieren que estas poblaciones podrían estar relacionadas con plantas invasoras de Estados Unidos. Debido al carácter extremadamente invasor de la especie, y a su posible origen secundario a partir de las poblaciones norteamericanas, se recomienda el seguimiento de estas poblaciones.

Palabras clave: Compositae; especie alóctona; península Ibérica. 


\section{INTRODUCTION}

Rhaponticum repens (L.) Hidalgo is a rhizomatous perennial plant native from Mongolia, West Turkistan, Iran, Armenia and Minor Asia that has become a noxious weed in several countries as Argentina, Canada, Germany, Russia and USA. It was purportedly introduced in the USA with contaminated alfalfa (Medicago sativa L.) seed shipments (Moore \& Frankton, 1974) and nowadays it is a serious pest, displacing native forage plants and reducing the wheat production up to $75 \%$ and corn up to $88 \%$ (Watson, 1980).

This species is usually reported in the literature as Acroptilon repens (L.) DC. However, latest systematic works, both on morphological (Dittrich, 1977) and molecular bases (Hidalgo et al., 2006), support the inclusion of Acroptilon Cass. within the genus Rhaponticum Vaill.

We report for the first time the presence of $R$. repens on abandoned fields of the village of Vilablareix, near the city of Girona (Catalonia, Spain). Simultaneously, the species has been identified from collections made in 1959 in Alicante, near Villena and Novelda, where its presence as a naturalized weed has been confirmed by recent collections. We also provide some population data and evidence of its possible origin using the comparison of ITS ribotypes from plants of different geographical origins.

\section{MATERIAL AND METHODS}

\section{ITS sequence analysis}

Total genomic DNA was extracted using the NucleoSpin ${ }^{\circledR}$ Plant Kit (Macherey-Nagel GmbH \& Co. KG, Düren, Germany) following the manufacturer's instructions for one individual from Vilablareix and other one from Villena. The ITS region was then amplified with primers 17SE and 26SE (Sun et al., 1994) as described in Garcia-Jacas et al. (2006). The PCR products was purified with ExoSAP-IT (USB Corp., Cleveland, $\mathrm{OH}, \mathrm{USA}$ ) and sequenced with 26SE primer at the University of Florida ICBR Core Facility using an ABI 3730x1 DNA analyzer (Applied Biosystems, Foster City, CA, USA). Vilablareix and Villena sequences were aligned and compared by eye with ITS accessions of $R$. repens from GenBank (Table 1) using Bioedit (Hall, 1999).

\section{Germination test}

Germination tests were undertaken with seeds from Villena population, under controlled conditions in Petri dishes on top of paper, using only distilled water to full moisten the filter paper. A set of 30 mature seeds was maintained in a growth chamber constantly at $25^{\circ} \mathrm{C}$, in a $16 \mathrm{~h}$ day / $8 \mathrm{~h}$ night photoperiod of cool-white fluorescent light.

\section{RESULTS AND DISCUSSION}

The population from Vilablareix (Girona province) grows in a grassland area, formely arable fields, which are grazed by sheeps in summer. It is found together with several annual species such as Avena barbata Pott ex Link, Torilis arvensis (Huds.) Link, Vicia sativa L. and Vulpia myuros (L.) C. C. Gmel., as well as the perennials Aster pilosus Willd., Cynodon dactylon (L.) Pers., Daucus carota L., Holcus lanatus L. and Trisetaria panicea (Lam.) Paunero. Its area of occupancy is less than $200 \mathrm{~m}^{2}$ and only 20 mature individuals were counted in July 2010 (Fig. 1). We were not able to find seedlings.

The populations located in the Vinalopó valley are four to date, all of them in the Alicante province: 'Novelda, prox. ferrocarril, $38^{\circ} 22^{\prime} \mathrm{N}, 0^{\circ} 51^{\prime} \mathrm{W}$, suelo arcilloso, 2.08.1959, A. Rigual s. n. (ABH 21300, MA 368369; as Centaurea jacea subsp. jacea)"; "Villena, Colonia Santa Eulalia, 38 34' N, $0^{\circ} 52^{\prime}$ 'W, 483 m, 26.05.1994, M. A. Alonso et al. s. n. (ABH 57869)"; "Villena, zona sur Prados de Galeno, $2 \mathrm{~km}$ al $\mathrm{N}$ de Colonia Santa Eulalia, pr. confluencia Acequia del Rey con río Vinalopó, $38^{\circ} 36^{\prime} \mathrm{N}, 0^{\circ} 51^{\prime} \mathrm{W}, 500 \mathrm{~m}, 4.06 .2011$, J. C. Cristóbal \& E. González s. n. (ABH 57874)". The species was always very abundant, around 5000 individuals in dense populations (Fig. 2), together with Atriplex halimus L., Salsola vermiculata L., Dactylis glomerata L., Centaurea calcitrapa L., C. aspera L., C. melitensis L., Scolymus hispanicus L., Carduus bourgaeanus Boiss. \& Reut., Marrubium vulgare L., Melica ciliata L., Echium asperrimum Lam., Piptatherum miliaceum (L.) Coss., Salsola kali L., Limonium echioides Mill., etc. They occur in waste places, next to cereal crops (mostly wheat), usually growing on deep, clayish, subsaline soils that remain somewhat humid until the early summer. This territory has a termo-mesomediterranean thermotype with a semiarid ombrotype (Rivas Martínez, 2007). 
Table 1. Origin of the materials and herbarium vouchers for the GenBank accessions.

\begin{tabular}{|c|c|c|}
\hline Acronym & Genbank accession & Origin of materials \\
\hline Vilablareix & JN202400 & $\begin{array}{l}\text { Spain, Girona, Vilablareix, } 41^{\circ} 57^{\prime} 30^{\prime \prime} \mathrm{N}, 2^{\circ} 47^{\prime} 50^{\prime \prime} \mathrm{E}, 100 \mathrm{~m}, 06.2009 \text {, Vilar s. } n . \\
\text { (BC 876276) }\end{array}$ \\
\hline Villena & JN639860 & $\begin{array}{l}\text { Spain, Alicante, Villena, zona sur Prados de Galeno, } 38^{\circ} 36^{\prime} \mathrm{N}, 0^{\circ} 51^{\prime} \mathrm{W}, 500 \mathrm{~m} \text {, } \\
\text { 4.06.2011, J. C. Cristóbal \& E. González s. } n .(\mathrm{ABH} 57874)\end{array}$ \\
\hline USA1 & HM009320 & USA, D. K. Berner \& M. L. Carter, unpublished \\
\hline USA2 & EU409919 & USA, Idaho, Ada Country between Boise and Nampa, Kinter s. $n$. (BC) \\
\hline USA3 & L35881 & USA, Washington: Hanford reservation, C. Talbot 1265 (WS) \\
\hline Kyrgyzstan & AJ867983 & Kyrgyzstan, Djalal-Abad oblast, valley of Beke-Cal river, 12.07.2003, L. Martins 870 (JE) \\
\hline Uzbekistan & AY826223 & Uzbekistan, 4 km south from Moynak, 1.01.1999, Susanna 2046 et al. (BC) \\
\hline
\end{tabular}

According to our observations, the species seems to have, presently, a limited invasive potential in the Vilablareix area, since its area of occupancy has remained relatively stable over the last 3-4 years. Alicante populations, although not invasive at present, are well established at least since the 50s and they seem naturalized, as evidenced by the persistence over time and the large number of individuals in populations. Nevertheless, the same as in Vilablareix, seedlings were not found. Furthermore, germination experiments carried out on the Alicante populations failed and not a single seed germinated.

Even though Iberian populations do not seem to have sexual reproduction at present, it could become an aggressive plant in the future, as it has been demonstrated in many countries, especially in the USA. Its invasive behaviour could be related to several factors like its high reproduction capacity, which may be sexual but more frequently clonal by

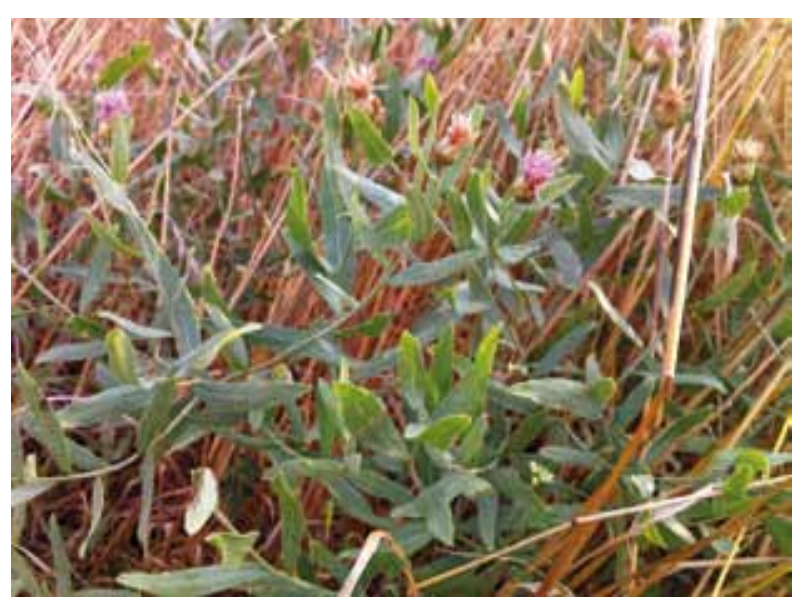

Figure 1. Individuals of Rhaponticum repens growing in Vilablareix locality. vegetative root shoots (Bezic et al., 2006/07), and to its competitive ability, which is increased by the combined effect of allelopathy and high resources uptake (Grant et al., 2003). For that reason it could become invasive in the future, therefore it would be appropriate to carry out a population monitoring at both Vilablareix and Villena sites.

The analysis of the ITS region evidences that Vilablareix and Villena plants share the same ri-

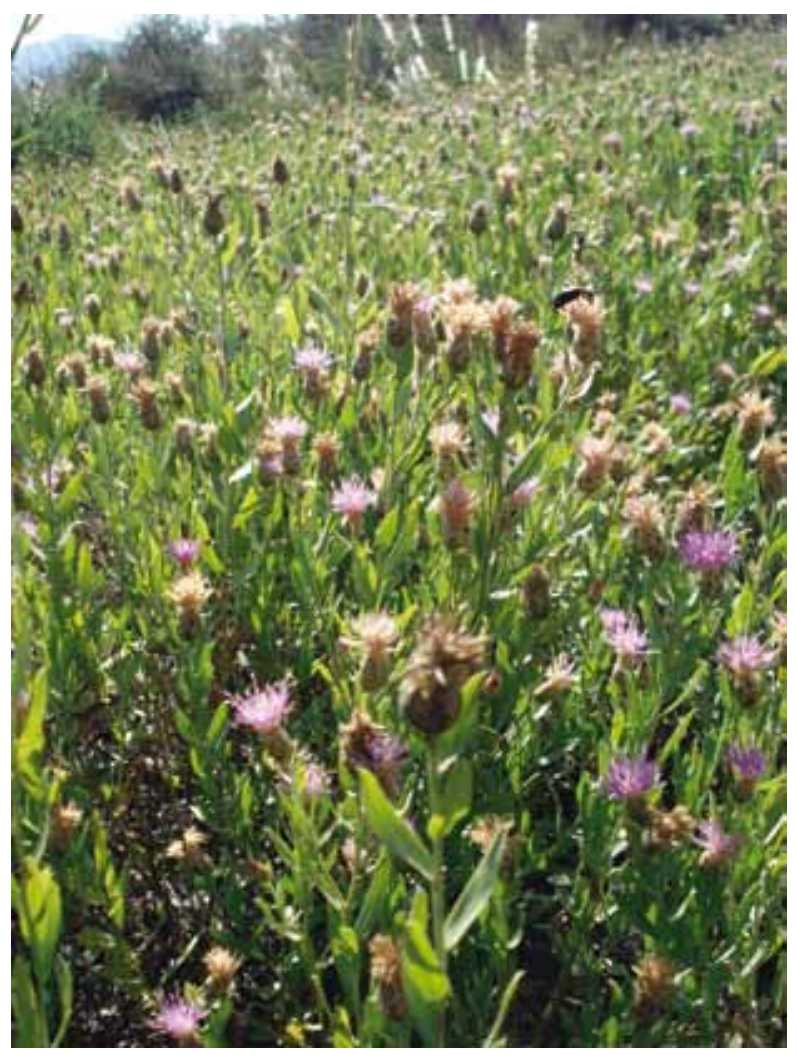

Figure 2. Individuals of Rhaponticum repens growing in Villena locality. Note the density of individuals. 
Table 2. Condensed alignment of two variable positions (column) in the nrDNA region ITS.

\begin{tabular}{|lcc|}
\hline Acronym & $\mathbf{2 3 1}$ & $\mathbf{4 4 3}$ \\
\hline Vilablareix & $\mathrm{C}$ & $\mathrm{C}$ \\
Villena & $\mathrm{C}$ & $\mathrm{C}$ \\
USA1 & $\mathrm{C}$ & $\mathrm{C}$ \\
USA2 & $\mathrm{Y}$ & $\mathrm{Y}$ \\
USA3 & $\mathrm{C}$ & $\mathrm{C}$ \\
Kyrgyzstan & $\mathrm{T}$ & $\mathrm{T}$ \\
Uzbekistan & $\mathrm{T}$ & $\mathrm{T}$ \\
\hline
\end{tabular}

botype as two American plants, characterized by two changes regarding to Central Asia accessions (Table 2). Spanish populations are more related to plants collected in North America than to the Asian ones, and the possibility of a secondary invasion for Villena and Vilablareix plants should not be neglected. However, this possibility should be taken with caution as the sampling is very scarce and nrDNA ITS often presents polymorphism, as evidenced in the USA2 accession. In fact, the American ribotype could be present in Central Asia populations too. Rhaponticum repens has demonstrated a very aggressive weedy habit in other parts of the world, especially in the United States. If Spanish plants have an American origin or share the geographical origin with the American invasive plants, maybe the potential to become a noxious weed could be higher.

The population of $R$. repens is unlikely to have long-term impact on the native vegetation of the Vilablareix area, but in any case we propose its eradication before this species become naturalized: once established, control or removal of invasive species may be very difficult (Duncan et al., 2003). Unfortunately, this approach is not suitable for the Alicante populations, which have been established for long. Some type of monitoring is strongly advisable, especially for controlling whether the species begins an expansion form its current habitat in waste lands and invades crop fields and natural vegetation.

As a corollary, we suggest to conduct more studies on Iberian herbaria since Alicante plants were unnoticed for years. Probably other herbarium sheets labeled as Centaurea jacea or other extant populations of Rhaponticum repens in the Iberian Peninsula will be detected.

\section{ACKNOWLEDGMENTS}

This study was supported by the Spanish Ministerio de Educación y Ciencia (project CGL2009-13322-C03-03/BOS), and by the Catalan Government ('Ajuts a Grups de Recerca Consolidats' 2009/SGR/00439-GREB).

\section{REFERENCES}

Bezic, C., Sabbatini, M. R. \& Dall'Armellina, A. 2006/07. Estatus y conflictos frente al proceso de invasión de Yuyo moro (Acroptilon repens (L.) DC.) en el valle inferior de Río Negro. Pilquen. Sección Agronomía 8: 2.

Dittrich, M. 1977. Cynareae - systematic review. In: Heywood, V. H., Harborne, J. B. \& Turner, B. L. (Eds.), The biology and chemistry of the Compositae. Academic Press, London: 999-1015.

Duncan, R. P., Blackburn, T. M. \& Sol, D. 2003. The ecology of bird introductions. Annual Rev. Ecol. Evol. Syst. 34: 71-98.

Garcia-Jacas, N., Uysal, T., Romashchenko, K., Suárez-Santiago, V. N., Ertuğrul, K. \& Susanna, A. 2006. Centaurea revisited: A molecular survey of the Jacea group. Ann. Bot. (Oxford) 98: 741-753.

Grant, D. W., Peters, D. P. C., Beck, G. K. \& Fraleigh, H. D. 2003. Influence of an exotic species, Acroptilon repens (L.) DC. on seedling emergence and growth of native grasses. Pl. Ecol. 166: 157-166.

Hall, T. A. 1999. BioEdit: a user-friendly biological sequence alignment editor and analysis program for Windows 95/98/ NT. Nucl. Acids Symp. Series 41: 95-98.

Hidalgo, O., Garcia-Jacas, N., Garnatje, T. \& Susanna, A. 2006. Phylogeny of Rhaponticum (Asteraceae, Cardueae-Centaureinae) and related genera inferred from nuclear and chloroplast DNA sequence data: Taxonomic and biogeographic implications. Ann. Bot. (Oxford) 97: 705-714.

Moore, R. J. \& Frankton, C. 1974. The thistles of Canada. Research Branch, Canada Department of Agriculture, Ottawa.

Rivas Martínez, S. 2007. Mapa de series, geoseries y geopermaseries de vegetación de España. Memoria del mapa de vegetación potencial de España. Parte 1. Itin. Geobot. 17: $1-435$.

Sun, Y., Skinner, D. Z., Liang, G. H. \& Hulbert, S. H. 1994. Phylogenetic analysis of Sorghum and related taxa using internal transcribed spacers of nuclear ribosomal DNA. Theor. Appl. Genet. 89: 26-32.

Watson, A. K. 1980. The biology of Canadian weeds. 43. Acroptilon (Centaurea) repens (L.) DC. Canad. J. Pl. Sci. 60: 993-1004. 